
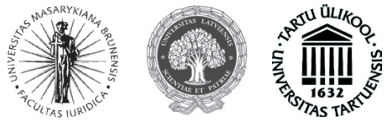

ISSN 2029-2236 (print) ISSN 2029-2244 (online)

SOCIALINIU MOKSLU STUDIJOS SOCIETAL STUDIES 2013, 5(4), p. 1086-1093.

\title{
INSTITUTIONAL CHANGES IN CONTEMPORARY THEATRE
}

\author{
Elena Dzikevich \\ High Theatre School named after M. S. Schepkin, \\ Department of Philosophy and Culturology \\ 109012, 6/2, Neglinnaya street, Moscow, Russia \\ Telephone: +7(495) 6231880 \\ E-mail: aesthesis@yandex.ru
}

Received on 31 August, 2013; accepted 21 October, 2013

doi:10.13165/SMS-13-5-4-08

\begin{abstract}
Current processes in international theatre practice have been so different in artistic sense that they could hardly be combined in some unity. But there is another criterion, not purely artistic, according to which artistically different phenomena of contemporary theatre could be united in wholeness. It is an institutional kind of criterion. Contemporary state of theatre as a kind of art could not be clearly described and then productively investigated without interpretation of those strong and deep transformations that have happened to theatre as a kind of societal institution. The thing is that researchers usually do observe artistic and societal qualities of art separately. Of course, it is one of the results of knowledge coming into depth and getting specialized, but sometimes it seems as if in development of art there were two divided processes - artistic, on the one hand, and societal, on the other hand. In reality, this development is one and whole total process with many various aspects. To keep in mind the unity of artistic and societal transformations of theatrical art is the challenge for methodological discourse within any aesthetic investigation in this field. Institutional theory of art, according to the author's point of view, is the very case of methodological attitude that allows a researcher stay realistic in relation to
\end{abstract}

Socialinių mokslų studijos / Societal Studies

(c) Mykolo Romerio universitetas, 2013

(C) Mykolas Romeris University, 2013
ISSN 2029-2236 (print), ISSN 2029-2244 (online) http://www.mruni.eu/lt/mokslo_darbai/SMS/ http://www.mruni.eu/en/mokslo_darbai/SMS/ 
the abovementioned unity. There is the key point that demonstrates it - the approach of the institutional theory of art to the problem of psychical distance between performance and spectators, its historical institutionalization in the phenomenon of classical and the following changes within this institutional state that finally brought theatre from classical to non-classical aesthetic regime. Institutional theory looks at this transition as artistic in the inspiriting causes, but societal is focused on fixation of their results. So, this theory allows an aesthetic observer keep the balance on the blade of the artistic and the societal contents of the institutional state of contemporary theatre. This article is the author's attempt to point out the most significant institutional changes in contemporary theatre.

Keywords: theatre, contemporary art, institutional theory of art, psychical distance, institutional transition.

\section{Introduction}

Since 1960s, researchers' attentive eyes have been capable to fix that theatre has been trying to overcome the borders, which according to the institutional theory must be called the institutional state of theatre as art. Surely, this tendency could be more or less evident in different schools and cases, e.g., if you take a street happening or a gallery performance, it is more evident. There are some features of a theatre action here, because it is a kind of a role game, but spectators are not supposed to be divided from actors. Oppositely, they are supposed to be involved to the very action of the role game. It could be remembered how George Dickie was commenting the case of a spectator of Shakespeare's Othello in the aspect of psychical distance in his Art and the Aesthetic... ${ }^{1}$. In the traditional state of theatre as art institution, it is a problem permanently being solved by great systems, schools, and, especially, by reformers of the scene. But a street happening and a gallery performance are out of this problem: the institutional state of this kind of art is starting at the point where division of actors and spectators has been overcome.

However, the most interesting cases of institutional transition of contemporary theatre are not so evident as in role games out of the theatre space. They are within this space, less evident, but stronger conceptually, e.g., in Russia, people can watch a very long Tom Stoppard's play The Coast of Utopia ${ }^{2}$. This is a great mental drama of the so called "everlasting ideas and questions" of Russian history. The play's context is their strange mixture appearing in characters' actions, gestures, quotations, speeches. Spectators are spending the whole day with breaks for coffee, lunch and dinner - and what is the result? The result is really great: they are losing control that is necessary for differing the time of the play and the time of their "actual" existence - they are starting to live their day in the action of "everlasting ideas and questions" and historic characters are becoming a sort of their friends or similar.

1 Dickie, G. Art and the Aesthetic. An Institutional Analysis. Ithaca: Cornell University Press, 1974, p. 100-112.

2 Stoppard, T. The Coast of Utopia. Trilogy. City: Faber and Faber, 2006. 
Institutional transition has many appearances, but it is a real and most common feature of contemporary theatre. The ways to investigate it are on the starting point.

\section{Classical Theatre}

Theatre as a regular kind of art was fully institutionalized in European mind by the intellectual movement, which is usually called Classicism, and one could be very precise when calling professional European theatre in traditional appearance classical. But in theoretical sense, this calling means some characters that cannot be fixed in everyday language. Common language used by the major part of spectators understands classical theatre as such a kind of performance, where spectators are separated from the action not only physically, but also psychically. Aesthetic interaction in this event is supposed to be strongly inspired with abstract thinking and mental processes, in which two interacting sides - performers and spectators - are involved according to their separated position in the event of performance. Common language, as usual, is fixing here some essential features of the surface of the phenomenon: in appearance, classical theatre is really institutionalized as division of two social positions in the event of performance: performers (authors, actors, all theatre staff as a whole) and spectators. If theoretical language is used, this division does not disappear, but oppositely, it is getting principle, because real theoretical principles are coming on the scene.

When starting to use theoretical language in order to try to understand what classical European theatre is, the first thing that is faced with is the origin of the very predication "classical". It is discovered that this predication is coming not from some habits and customs, but from aesthetic discourse of Classicism, which constructed theoretical standards for art and its kinds from some basic elements. These elements had had some meanings of their own outside the new context of Classicism, e.g. Aristotle's Poetics ${ }^{3}$ or Descartes' Discourse on the Method...4, but within the context these meanings were transformed into the whole and integral meaning of the classicist doctrine (generally exposed by Boileau-Despréaux in his The Art of Poetry (L'Art Poétique $)$ ). This doctrinal meaning was supposed to be deduced for every art creation (playwright or performance) by its authors and then spectators were expected to identify this doctrinal message and to enjoy this identification. So, the level of artistic perfection of a theatre event was thought as the grade of artifactuality of performance, e.g., all spectators knew that principles of unity (time, place, action) were artificial, belonging to reality of artistic creation and not to

3 Aristotle. Poetics. Transl., with introduction and notes by J. Sachs. Newburyport, MA: Focus Publications, 2006.

4 Descartes, R. Discourse on the Method of Rightly Conducting One's Reason and Seeking Truth in the Sciences.

Transl., with an interpretive essay by R. Kennington (Ed.), with introduction, glossary, and notes by P. Kraus and F. Hunt. Newburyport, MA: Publisher, 2007.

5 Boileau, N. The Art of Poetry and Lutrin. Transl. by Sir William Soames and J. Ozell. Richmond, Surrey: Oneworld Classics, 2008. 
reality outside the theatre, but this fact did not oppose them to the performance, it was the code to the message, which, when opened with this code, could bring aesthetic enjoyment.

Since that time, theatre doctrines have changed many times, classical theatre has not been classicist for a very long time, but it has remained classical in all cases, where one must identify the doctrinal code of the theatre art to enjoy the performance. It can be seen that psychical distance between two modes of reality - theatrical and spectator's existential ones - are necessary in classical performance. This distance in the case of classical performance is supposed to be overcome only intellectually, as a chain of implicit or explicit conclusions determined by the very aesthetic experience. So, classical theatre performance is institutionalized under professional formula more art - more appreciation.

In Russia and maybe in the rest of the world, the culmination of theatre development, according to this formula, was reached in Stanislavsky's system. Moscow Artistic Theatre that was based on it gave the world history of theatre a case of institution, where all events were supposed to be fit or not only according to the criteria of artistic perfection (Stanislavsky's famous verdict $I$ don't believe... meant that the actor was not perfect in his art to be psychologically true in his role ${ }^{6}$ ). Spectators should have recognized actors' art to deliver the psychological truth of their characters and then to conclude the general meaning of the message in the intellectual work of their minds outside the theatre. This criterion of artistic perfection as psychological truth was a real border of classical theatre based on psychical distance between theatre reality and spectator's personal existential reality.

\section{Non-Classical Theatre}

After this, it is easier to understand (especially remembering that Stanislavsky's system was well known over the world) that further development of theatrical art had to turn on the way of non-classical experiments. In the 20th century, since the middle of the 1920s, a lot of attempts to overcome psychical distance between actors and spectators during the performance were faced with, e.g., actors could go from the stage to spectators for a while or a few rows of spectators' chairs could be placed on the stage, sometimes characters could directly appeal to spectators, etc. All such attempts contrasted to classical criteria of theatre performance and, thanks to that, contrasts were more or less successful and known. It must be said that such experiments were a general tendency in all countries with developed theatrical culture of European performance mode, but they were within its classical type, expressively dancing on its borders, incapable to destruct them. More fundamental reasons than artistic will were necessary for institutionalizing changes in a great public art, such as theatre: only after WWII, when the world was psychologically shocked and needed post-shock therapy, it came in the face of institutional changes in all of arts simultaneously - cinema, theatre, music, painting, sculpture, literature. It was a great influence of society in general on the art world that the art world could accept deconstruction of borders between kinds and genres of arts. 
Since the middle of the 1950s, it turns out that the main tendency in history of all arts and for history of theatre, it has been the period, when psychical distance between performers and spectators was finally overcome, partly as the direct result of the psychological shock, partly thanks to influence of other arts. Since 1960s, with social changes of those times that brought on social and theatrical scene a lot of young creative and energetic people non-classical mode of performance has been absolutely institutionalized: such a kind of artistic event as happening left psychical distance between performers and spectators in the past. Since those times, it seems that the professional motto of theatre has been less art, more appreciation.

\section{Institutional Transition of Theatre Art: Essential Details}

To realize the essence of this institutional transition, one must think of the character of the most fundamental changes that erased the psychical distance between performers and spectators in the non-classical performance. First of all, it means that the action that is shown must be less artificial, or ideally seem to be non-artificial at all. Here, performers must refuse from all mimetical habits of work with time and space in a performance. Spectators must not feel that what is happening is mimesis, imitation of anything, even of something essential and significant. They must feel that they are at least observers, actually co-existing to the performed events. So, the space of the stage must lose all features reminding imitations and reconstructions of anything, artistic time of performance must go as current time. This is the frame of work in conditions of the non-classical performance. Now, some significant details that have already appeared in this frame can be discussed.

First of all, documentary kind of details that are sort of telling spectators that the reality of performance is of non-theatre nature must be mentioned. There are a lot of ways to use such details: to show a story from yesterday's popular Internet blogs, to mix blogging actors with bloggers, who are not actors, to use Internet slang. Internet here is mentioned because today everybody knows that to be on the Internet and just to be or to exist is almost the same for a great number of people. Generally speaking, documentary details are showing spectators how non-artificially real are the events of the performance.

The second kind of details is concerned with temporary feeling itself, e.g., telling a story of a real historic person, one can rarely use documentary details not constructing the border of psychical distance between performers and spectators. However, one can force spectators to feel as time is going in one temp as it is going for characters. It is the case of Tom Stoppard's The Coast of Utopia, where characters are real persons of history and the play lasts so long, that people really feel that they live simultaneously with them.

The third kind of details is concerned with artistic qualities of acting performers. The word "actors" is not used here specifically. In classical mode of performance, actors are supposed to be prepared in special institutions, they must be taught to speak, move, express the psychical states of their characters with all their bodily capabilities, understand their role in the general message of performance. Spectators are supposed to appreciate all these qualities of professional preparation. Non-classical mode of performance needs some additional qualities to this set: an actor must be capable to cover his special education 
and to look as if he were non-taught and not-prepared. It is especially significant, when in one action professional actors and non-professional performers are combined (e.g., in documentary drama). So, even in the case of artistic qualities, if their artificial nature is less evident, appreciation is higher.

\section{Conclusions}

These three kinds of essential details characterizing non-classical mode of theatre performance do not exhaust theoretical content of institutional transition in contemporary theatrical culture. In the order of importance for institutional transition, or according to their institutionalizing force, they include the following: documentary details, details of temporary feeling itself, details concerned with artistic qualities of acting performers. In the article, the author specifically used the word detail for signification of what the author wanted to point at - this means mental elements of the aesthetic construction, which is equal with the message of contemporary theatre performance. So, the word detail must be understood in the context of this article as the carrier of the results, delivered by theoretical deconstruction of the message of this type. The author does not insist on these details being in final and full enumeration, but in their being the basic ones. The author also wants to pay attention to the fact that in the process of the institutional transition of theatrical art to contemporary state there are some significant features demonstrating unrecoverable historical changes, leading to domination of non-classical mode of performance and marginality of the classical one.

It means that even old and solid theatre standards, such as classical opera, must possess strong support from the side of documentary details to be capable to stay in the zone of aesthetic attention of contemporary audience, which is ready to come in the regime of aesthetic enjoyment of it only when appreciating it as a kind of a role game in current time. So, the largest opera companies have made the documentary support their everyday artistic and promotional (societal) practice. Direct TV and Internet shows, various ways to overcome psychical distance during the performance (modern costumes and scenic infrastructures, cases of non-formal liberties in the manners of singers, conductors and orchestra musicians), outdoor performances and concerts, events and records in collaboration with non-opera stars should be mentioned here, as well.

All these documentary details lead to the fact that classical opera as a kind of theatrical art can survive only when its leading persons keeping their great singing and other music skills are starting to act as performers: only in this case the audience is capable to feel the time of duration of a classic opera performance as their actual time. Here, it can be seen how documentary details of a contemporary theatre message are turning into details of temporary feeling itself and it is exactly this factor that directly makes a classic opera performance contemporary in perception - it delivers the content of contemporariness into general impression of the event. Surely, in this situation opera performers are supposed to posses some extra artistic qualities if these qualities are compared with those, that are necessary in the classic set of an opera singer, orchestra conductor or musician.

This third kind of details is the hardest for conceptual understanding and most demonstrative in the case of a classic opera performance to overcome marginality on 
contemporary theatre scene. The author specifically mentioned it because of the question that was asked about it after the presentation on this problem at The 19th Congress of Aesthetics (Krakow, Jagellonian University, July, 2013). The question was how can classic opera singing get less artistic to bring more appreciation not loosing essential qualities of opera in general, or is opera not involved in the process at all? The answer is as follows: opera is involved in the process and it is the most characteristic case of it, in which it can be seen that contemporary artistic qualities, thanks to which art looks non-artificial, are not instead of but extra to traditional artistic qualities. The unrecoverable marginality of classic qualities to non-classic is in the fact that the first cannot be evaluated without the second one any more in the case of the dominating part of contemporary audience.

\section{References}

Aristotle. Poetics. Transl., with introduction and notes by J. Sachs. Newburyport, MA: Focus Publications, 2006.

Boileau, N. The Art of Poetry and Lutrin. Transl. by Sir William Soames and J. Ozell. Richmond, Surrey: Oneworld Classics, 2008.

Descartes, R. Discourse on the Method of Rightly Conducting One's Reason and Seeking Truth in the Sciences. Transl., with an interpretive essay by $\mathrm{R}$.
Kennington (Ed.), with introduction, glossary, and notes by P. Kraus and F. Hunt. Newburyport, MA: Publisher, 2007.

Dickie, G. Art and the Aesthetic. An Institutional Analysis. Ithaca: Cornell University Press, 1974, p. 100-112.

Stanislavski, C. An Actor's Work: A Student's Diary. Trans. and ed. by J. Benedetti. City: Routledge, 2008.

Stoppard, T. The Coast of Utopia. Trilogy. City: Faber and Faber, 2006.

\section{INSTITUCINIAI POKYČIAI ŠIUOLAIKINIAME TEATRE}

\section{Elena Dzikevich}

Aukštoji M. S. Schepkino vardo teatro mokykla, Rusija

Santrauka. Dabartiniai tarptautines teatro praktikos procesai menine prasme yra tokie skirtingi, kad juos sunku susieti i tam tikrq vienovę. Vis dèlto yra kitas, ne grynai meninis kriterijus, kuriuo remiantis galima sujungti $i$ visuma menine prasme skirtingus šiuolaikinio teatro fenomenus. Tai institucinio pobūdžio kriterijus. Be tu svarbių teatre kaip socialinèje institucijoje ìvykusių transformaciju interpretacijos negalima būtu aiškiai aprašyti ir po to produktyviai tyrinèti šiuolaikinio teatro kaip meno rūšies padèties. Esmè ta, kad tyrinètojai paprastai meno menines ir socialines savybes stebi atskirai. Žinoma, tai yra vienas iš i gilumą besismelkiančio ir besispecializuojančio mokslo rezultatu, bet kartais atrodo, lyg būtu du atskiri meno raidos procesai, iš vienos pusés - meninis, iš kitos - socialinis. Iš tikruju ši raida yra vienas, vientisas ir bendras procesas, apimantis daug skirtingu aspektu. 
Metodologiniam kiekvieno estetinio šios srities tyrinėjimo diskursui kyla iššūkis neužmiršti meninių ir socialinių teatro meno transformacijų vienovès. Autorès požiūriu, institucinè meno teorija kaip tik ir yra metodologinès nuostatos, leidžiančios tyrinètojui iš tikruju atsižvelgti i minètają vienovę, pavyzdys. Svarbiausias tai atskleidžiantis dalykas yra institucinés meno teorijos požiūris ị tarp spektaklio ir žiūrovu susidarančia psichinę distanciją, jos istorinę institucionalizaciją klasikoje ir véliau vykusius jos institucinio statuso pokyčius, galiausiai pakeitusius klasikinį teatro estetinị režima neklasikiniu. Institucinè teorija dèl ši pokyti paskatinusiu priežasčiu i jị žvelgia kaip ị meninį, o dèl ju pasekmiu įtvirtinimo - kaip i socialinį. Tad ši teorija leidžia stebètojui išlaikyti pusiausvyrą tarp šiuolaikinio teatro institucinés padèties meninio ir socialinio turinio. Šis straipsnis yra autorès pastanga išryškinti pačius reikšmingiausius institucinius šiuolaikinio teatro pokyčius.

Reikšminiai žodžiai: teatras, šiuolaikinis menas, institucinè meno teorija, psichine distancija, institucinis pokytis.

Elena Dzikevich, Aukštosios M. S. Schepkino vardo teatro mokyklos Filosofijos ir kultūrologijos skyriaus profesorè. Mokslinių tyrimų kryptys: filosofijos istorija, estetika, teatro istorija ir filosofija.

Elena Dzikevich, High Theatre School named after M. S. Schepkin, Department of Philosophy and Culturology, Professor. Research interests: history of philosophy, aesthetics, history and philosophy of theatre. 